\title{
First Report of Phanerotoma bennetti Muesebeck (Hymenoptera, Braconidae, Cheloninae) Parasitizing Hypsipyla grandella (Zeller) and Hypsipyla ferrealis Hampson (Lepidoptera, Pyralidae) in Crabwood in Brazil
}

\author{
Pinto, AA. ${ }^{a *}$, Teles, BR. ${ }^{b}$ and Penteado-Dias, AM. ${ }^{c}$ \\ ${ }^{a}$ EcoTec Pragas Urbanas, Rua Jornalista Helder Feitosa, 1267, CEP 64049-753, Teresina, PI, Brasil \\ ${ }^{b}$ Coordenação de Biodiversidade, Instituto Nacional de Pesquisas da Amazônia, Av. André Araújo, 2936, Aleixo, \\ CEP 69060-000, Manaus, AM, Brazil \\ 'Departamento de Ecologia e Biologia Evolutiva, Universidade Federal de São Carlos - UFSCar, \\ Rodovia Washington Luiz, Km 235, CEP 13565-905, São Carlos, SP, Brazil \\ *e-mail: adr.araujop@gmail.com
}

Received: November 6, 2012 - Accepted: December 27, 2012 - Distributed: February 28, 2014

Crabwood [Carapa procera DC. (Meliaceae)] is an Amazonian species with great commercial potential. Plants in the Meliaceae family are widely used by insects, which often become serious forest pests. Infestation by Hypsipyla Ragonot (Lepidoptera, Pyralidae) makes it unfeasible to cultivate these Meliaceae. Hypsipyla larvae apparently feed exclusively on Meliaceae, subfamily Swietenioideae, including plants of high economic value such as those in the genera Swietenia Jacquin, Khaya A.Juss, Toona Endlicher, and Cedrela P. Browne (Griffiths, 2001).

Biological control of Hypsipyla is an important strategy to be implemented as part of the integrated management of these pests in Meliaceae. s. However, little is known about their native natural enemies.

This is the first report of the parasitoid Phanerotoma bennetti Muesebeck, 1955 (Hymenoptera, Braconidae) attacking Hypsipyla grandella (Zeller) and Hypsipyla ferrealis Hampson (Lepidoptera, Pyralidae) in the crabwood Carapa procera DC. (Meliaceae), State of Amazonas, Brazil.

Thirty-eight specimens of $P$. bennetti were collected on larvae and pupae of $H$. grandella and $H$. ferrealis in Carapa procera in the Ducke Forest Reserve ( $02^{\circ} 55^{\prime}-03^{\circ}$ $01^{\prime} \mathrm{S}$ and $\left.59^{\circ} 53^{\prime}-59^{\circ} 59^{\prime} \mathrm{W}\right)$, in fifteen samples collected in April-May 2006. Voucher specimens were deposited in the Invertebrate Collection of the Instituto Nacional de Pesquisas da Amazônia (INPA) Manaus, Brazil and in the Collection of the Departamento de Ecologia e Biologia Evolutiva (DCBU), Universidade Federal de São Carlos in São Carlos, São Paulo, Brazil.

Several families of parasitoids (Braconidae, Ichneumonidae, Chalcididae, Trichogrammatidae) have been reported as natural enemies of the immature stages of $H$. grandella in Central America, North America, South America, and Africa, including Hypomicogaster hypsipylae (Hymenoptera, Braconidae, Microgastrinae) (Desantis, 1973) and Trichogramma semifumatum Perkins (Hymenoptera,
Trichogramatidae) on H. grandella eggs (Grijpma, 1973). For $H$. ferrealis, the only parasitoids reported to date are Trichogrammatidae in Costa Rica, Trinidad, and Venezuela (Sands and Murphy, 2001).

In Brazil, Podogaster townesi (Graf 1983) (Hymenoptera, Ichneumonidae, Anomaloninae) has been reported on pupae of H. robusta (Sands and Murphy 2001), and Trichogrammatomyia tortricis Girault, 1916 (Hymenoptera, Trichogrammatidae) has been reported on eggs of H. grandella (Ohashi et al., 2005). There have been reports of the introduction of the parasitoids Trichogrammatoidea nana, T. robusta, and Phanerotoma sp. for biological control (Sands and Murphy, 2001). However, these need to be confirmed, as the information is vague.

As yet, there is no efficient means for the control of Hypsipyla pest species through the use of natural enemies in commercial plantations (Newton et al., 1993). The discovery of Phanerotoma bennetti as a parasitoid of Hypsipyla represents a possibility for the biological control of these species in seeds of $C$. procera.

Acknowledgements - We thank Dr. Vitor O. Becker for identifying the Pyralidae.

\section{References}

DESANTIS, L., 1973. Um novo microgasterino neotropico (Hymenoptera, Braconidae) parasito de la larva. Miscellaneous publication IICA, vol. 101, p. 71-72.

GRIFFITHS, MW., 2001. The Biology and Ecology of Hypsipyla Shoot Borers. In FLOYD, R.B. and HAUXWELL, C. (Ed.). Hypsipyla Shoot Borers in Meliaceae. Proceedings of an International Workshop. AuACIAR Proceedings no. 97, 189 p.

GRIJPMA, P., 1973. Studies on the shootborer Hypsipyla grandella (Zeller). Lep., Pyralidae. IICA Misc. Publ. vol. I, no. 101, 91 p.

NEWTON, AC., BAKER, P., RAMNARINE, S., MESEN, JF. and LEAKEY, RRB., 1993. The mahogany shoot borer: prospects for 
control. Forest Ecology and Management, vol. 57, p. 301-328. http://dx.doi.org/10.1016/0378-1127(93)90179-Q

OHASHI, OS., SILVA JÚNIOR, ML., LAMEIRA, OA., SILVA, JNM., LEÃO, NVM., TEREZO, EF., BATISTA, TFC., HIDAKA, DZL., ALMEIDA, GB., BITTENCOURT, PRG., GOMES, FS. and NEVES, GAM., 2005. Danos e contole da broca Hypsipyla grandella em plantio de Mogno Swietenia macrophylla no
Estado do Pará. In POLTRONIERI, L.S., TRINDADE, D.R. and SANTOS, IP. (Eds.). Pragas e doenças de cultivos amazônicos. Belém: Embrapa Amazônia Oriental. 483 p.

SANDS, D P.A. and MURPHY, S.T., 2001. Prospects for Biological Control of Hypsipyla spp. with Insect Agents. In FLOYD, R.B. and HAUXWELL, C. (Eds.). Hypsipyla Shoot Borers in Meliaceae. Proceedings of an International Workshop. AuACIAR Proceedings no. 97, 189 p. 